\title{
Tradisi Larung Saji Sebagai Upaya Menjaga Ekosistem Di Wisata Telaga Ngebel Ponorogo (Studi Literatur)
}

\author{
Lina Yuliamalia \\ Program Studi Ilmu Lingkungan, Pascasarjana, Universitas Sebelas Maret
}

\begin{abstract}
Abstrak
Penelitian ini bertujuan untuk mengetahui tradisi larung saji sebagai upaya menjaga ekosistem di wisata Telaga Ngebel Ponorogo. Penelitian yang digunakan adalah dengan studi literatur. Sumber data yang dibutuhkan dalam penulisan ini adalah dengan mengumpulkan informasi dari sumber tertulis, seperti majalah, artikel, jurnal, bukubuku, atau dokumen-dokumen yang sesuai dengan permasalahan yang dikaji. Selanjutnya data dianalisis dengan menggunakan teknik analisis isi, yaitu penelitian bersifat membahas isi informasi dalam media masa. Hasil dari penelitian ini adalah (1). Proses tradisi upacara larung saji, (2). Maksud dan tujuan tradisi juga sangat berpengaruh terhadap lingkungan sekitar terutama alam, dan (3). Manfaat larung saji sebagai upaya menjaga ekosistem Telaga Ngebel.
\end{abstract}

Kata Kunci: Larung Sesaji, Ekosistem, Ngebel

\section{Pendahuluan}

Indonesia adalah salah satu negara yang kaya akan ragam budaya. Setiap daerah di Indonesia memiliki ciri khas kebudayaan masing-masing, contohnya Reog (Ponorogo), Karapan Sapi (Madura), Ludruk (Jawa Timur), Ondel-ondel (Betawi), dan lain-lain. Tidak hanya budaya yang beraneka ragam di Indonesia, tetapi juga Indonesia memiliki adat istiadat yang luar biasa (Nur'aini, Nining, dkk. 2013). Salah satu adat istiadat yang menonjol di Indonesia adalah Upacara Ritual Larung Saji di Telaga Ngebel Ponorogo.

Upacara tersebut digelar setiap pergantian Tahun Baru Hijriyah (kalender Islam). Sebagai sarana menunjukkan rasa syukur dan upaya untuk mempererat tali silaturahmi antar masyarakat. Upacara adalah tindakan yang diatur oleh hukum atau adat yang ada dalam kehidupan masyarakat dan berhubungan dengan berbagai peristiwa yang terjadi di masyarakat (Koentjaraningrat, 1980: 140). Ritual merupakan suatu bentuk penghormatan yang berkaitan dengan kepercayaan dengan ditandai sifat khusus dalam pengalaman suci (Rostiyati, 1994: 1). Upacara ritual adalah wujud keyakinan, gagasan terhadap Tuhan, Roh-roh halus, Dewa-dewa, dan sebagainya, tetapi berwujud upacara dan mempunyai sifat musiman (Koentjaraningrat, 2002: 204).

Upacara ritual merupakan tindakan yang berhubungan dengan kepercayaan pada kekuatan benda-benda alam dan roh halus serta kekuatan gaib yang dilakukan pada waktu tertentu, seperti Sadranan, Sedekah Bumi, Sedekah Laut, dan Suran (Koderi, 1991: 109). Upacara ritual adalah sebuah tindakan penghormatan yang masih berhubungan dengan hal-hal gaib dalam pelaksanaanya dan dilakukan pada waktuwaktu tertentu. Dalam Kamus Besar Bahasa 
Indonesia (KBBI) kata Larung adalah membiarkan hanyut atau menghanyutkan, sedangkan Saji adalah persembahan sajian berupa makanan atau benda lain. Larung saji adalah menghanyutkan persembahan berupa makanan atau benda lain dalam upacara keagamaan dengan simbolis. Upacara larung saji adalah bentuk rasa syukur kepada Tuhan Yang Maha Kuasa yang telah memberikan rejeki yang melimpah terutama dalam bentuk hasil bumi untuk masyarakat.

Kabupaten Ponorogo merupakan salah satu tempat hidup fauna dan flora yang dapat tumbuh dan berkembang dengan baik. Berdasarkan Undang-undang Perlindungan dan Pengelolaan Lingkungan Hidup (PPLH) Nomor 32 Tahun 2009, ekosistem adalah kesatuan yang menyeluruh antara unsur-unsur yang berpengaruh dalam lingkungan hidup, baik itu abiotik maupun biotik atau makhluk hidup maupun benda mati.

\section{Menurut Soemarwoto (1983),} ekosistem adalah hubungan timbal balik antara makhluk hidup dengan lingkungannya. Ekosistem dapat diartikan sebagai suatu kesatuan kompleks yang didalamnya terdapat hubungan antara organisme dan lingkungannya yang saling mempengaruhi. Ada beberapa peneliti terdahulu yang banyak membahas tentang tradisi ritual adat dari beberapa wilayah di Indonesia. Pertama, penelitian dengan objek yang berbeda namun fokus pembahasan sama yaitu tentang adat istiadat sesaji upacara tradisional. Penelitian ini menghasilkan makna kultural masyarakat Wonogiri dengan adanya penjamasan pusaka dan percaya bahwa benda-benda pusaka mempunyai kekuatan gaib. Apabila benda pusaka dirawat maka akan mendatangkan berkah, jika tidak dirawat maka isi didalam akan pudar bahkan hilang (Nanda Fauza, 2010).

Kedua, objek penelitian yang samasama fokus pada tradisi larung saji di Telaga Ngebel. Hasil analisisnya mengarah pada rangkaian acara bermakna simbolik pada upacara larungan yang rutin digelar setiap malam 1 Suro (kalender Jawa) dan tinjauan dari beberapa aspek (Maulana Mitanto dan Abraham Nurcahyo, 2012). Ketiga, penelitian Dicky Reza R. (2013) yang menjelaskan nilai-nilai kearifan lokal pada upacara larung saji di Telaga Sarangan.

Hasilnya upacara tersebut dilakukan setiap tahun menjelang Ramadhan pada Jum`at Pon bulan Ruwah yang memiliki nilai rendah hati, religi, keindahan, kekerabatan, hingga nilai simbolik. Keempat, penelitian Rusmawati dan Suharti (2016) yang menganalisis manfaat tradisi larung saji terhadap sarana dan prasarana pariwisata Telaga Ngebel. Kelima, analisis ini mengangkat tema ragam kuliner yang disajikan dalam upacara tradisi di Jepara sebagai destinasi wisata (Sri Indrahti, et al. 2017). Penelitian ini 
untuk mengetahui bagaimana perubahan maupun perkembangan yang lebih dirasakan oleh masyarakat lokal Telaga Ngebel dan lingkungan sekitar dari tahun ke tahun sesuai dengan penelitian yang ada sebelumnya. Telaga Ngebel memiliki beberapa kegiatan untuk menjaga tradisi, juga berfungsi untuk membuat wisatawan tertarik mengunjungi tempat tersebut. Upacara larung saji di Telaga Ngebel dilakukan setiap tahun pada malam pergantian tahun baru Hijriyah.

Alasan melaksanakan upacara adalah sebagai sarana meminta keselamatan kepada Tuhan Yang Maha Esa karena tempat tersebut angker dan sering terjadi kecelakaan hingga meninggal dunia. Selain itu juga, sebagai tujuan pariwisata baik wisatawan dari dalam maupun luar kota bahkan luar negeri. Selanjutnya juga sebagai upaya untuk selalu menjaga ekosistem agar tetap terjaga keseimbangannya (Rusmawati dan Suharti, 2016).

Upacara ini dilaksanakan dalam dua tahap, yaitu pada malam dan pagi hari. Larungan malam hari dilakukan pada tengah malam dengan membawa saji berupa buceng beras merah yang didukung dengan beberapa kegiatan seperti selamatan, tanam syarat, dan pentas wayang. Larungan pada pagi hari dilakukan dengan beberapa kegiatan seperti pembukaan, kirab, serah terima sesaji, dan larungan menuju ke tengah telaga sebagai puncak acara. Kegiatan larung saji itu mempunyai beberapa tujuan seperti melestarikan budaya nilai-nilai luhur yang khas dan merupakan ciri masyarakat lokal dalam melanjutkan warisan leluhur. Tradisi-tradisi tersebut memiliki nilai religi yang besar bagi penduduk masyarakat setempat, apabila telah memakan makanan yang ada pada sesaji tersebut maka akan mendapatkan ketenangan batin maupun jiwa dan rasa aman dalam kehidupan (Rusmawati dan Suharti, 2016).

\section{Metode Penelitian}

Metode Penelitian yang digunakan adalah dengan studi literatur. Studi literatur adalah kegiatan mencari informasi dari beberapa sumber yang dilakukan dengan menggunakan metode mengumpulkan, membaca, dan mencatat, serta mengolah informasi (Zed, 2008: 3). Studi literatur dilakukan setelah mereka menemukan topik utama dalam penelitian dan menetapkan rumusan masalah, sebelum mengumpulkan data yang dibutuhkan dan terjun ke lapangan langsung (Darmadi, 2011).

Sumber data yang dibutuhkan dalam penulisan ini adalah dengan mengumpulkan informasi dari sumber tertulis, seperti majalah, artikel, jurnal, buku-buku, atau dokumen-dokumen yang sesuai dengan permasalahan yang dikaji. Selanjutnya data dianalisis dengan menggunakan teknik analisis isi, yaitu 
penelitian bersifat membahas isi informasi dalam media massa. Lokasi penelitian ini dilakukan di sekitar wilayah Telaga Ngebel Kecamatan Ngebel Kabupaten Ponorogo yang terletak di kaki Gunung Wilis.

Lokasi ini dipilih karena mempunyai potensi wisata yang unik dilihat dari kebudayaan dan keindahan alam, serta masih sangat alami untuk dikunjungi. Alam yang masih asri menambah destinasi wisata sehingga tidak heran jika tempat ini selalu ramai untuk dikunjungi.

\section{Hasil Dan Pembahasan}

\section{A. Deskripsi Wilayah \\ 1. Kondisi Fisik}

Seperti Telaga Ngebel terletak di koordinat $\quad 7047^{\prime} 49^{\prime} \mathrm{LU} \quad 111037^{\prime} 54^{\prime} \mathrm{BT}$ Kecamatan Ngebel Kabupaten Ponorogo Provinsi Jawa Timur, berada tepat di kaki Gunung Wilis yang berjarak sekitar \pm 30 km dari pusat kota Ponorogo. Sekelilingnya sekitar $\pm 5 \mathrm{~km}$ dengan suhu antara $20-26$ derajat celcius dan mempunyai curah hujan antara 1907-4593 mm/tahun serta berada pada ketinggian \pm 734 meter diatas permukaan laut (mdpl) (Dinas Pekerjaan Umum Bidang Pengairan, 2001-2010).

Asal air Telaga Ngebel adalah dari air hujan langsung maupun overlandflow dan muara sungai di sebelah utara yang terus mengalir ke selatan (BAPPEDA, 2008). Telaga ini dapat menampung air sebesar 24.220.000 $\mathrm{m}^{3}$, yang dapat digunakan untuk peternakan ikan, pengairan tanaman warga sekitar, dan pembangkit tenaga listrik. Pemanfaatan lahan di Kecamatan Ngebel yaitu kawasan wisata, kawasan hutan konservasi, kawasan perekonomian, kawasan perkantoran, kawasan pemukiman penduduk, dan fasilitas pendukung (BAPPEDA, 2008).

\section{Kondisi Sosial Ekonomi}

Penduduk Kecamatan Ngebel sebanyak 20.878 jiwa dengan 10.526 jiwa laki-laki dan 10.352 jiwa perempuan (BPS: 2015). Perekonomian yang paling dominan adalah pertanian dan pariwisata. Fasilitas yang ada di Kecamatan Ngebel meliputi fasilitas tempat ibadah, pendidikan, kesehatan, perdagangan dan jasa.

\section{Akses}

Akses jalan untuk menuju ke Telaga Ngebel dapat ditempuh melalui 2 jalur, yaitu dari Kota Ponorogo dan Kecamatan Dolopo Kabupaten Madiun.

a) Jika dari arah selatan ambil jalur Kota Ponorogo menuju arah Kecamatan Jenangan kemudian belok kanan mengikuti rambu sampai ke Telaga Ngebel.

b) Jika dari arah utara bisa langsung masuk jalur Kota Madiun kemudian kearah selatan hingga Kecamatan Dolopo kemudian belok kiri mengikuti rambu sampai ke Telaga Ngebel.

Daya tarik utama yang dimiliki oleh Telaga Ngebel adalah menikmati pemandangan alam yang masih alami dengan perpaduan antara bukit hijau dan 
danau. Di sebelah Barat danau kondisinya berbukit dan sepi pengunjung, sedangkan di Timur danau menyediakan banyak fasilitas wisata dan pengunjungnya lebih ramai daripada disebelah Barat (https://www.netizenpintar.com/2018/04 /jalan-menuju-telaga-ngebelponorogo.html ).

\section{B. Tujuan Larung Sesaji}

Larung saji dilaksanakan untuk dua tujuan, yaitu tradisi dan pariwisata. Tujuan tradisi ini juga berpengaruh terhadap lingkungan sekitar terutama alam. Masyarakat bersyukur karena diberikan kekayaan alam yang melimpah berupa Telaga Ngebel yang menjadi sumber penghidupan warga sekitar. Sehingga rasa syukur kepada Tuhan Yang Maha Kuasa diwujudkan dengan mengikuti tradisi dari nenek moyang mereka. Tradisi larung saji dilaksanakan sebagai upaya pencegahan kecelakaan karena zaman dahulu sebelum adanya tradisi ini banyak terjadi kecelakaan hingga terjadi korban jiwa.

Oleh karena itu, upaya yang dilakukan oleh pemimpin dan masyarakat sekitar adalah dengan berkumpul dan memutuskan bahwa diadakan tradisi larung saji setiap tahun baru Hijriyah yang sekaligus sebagai penarik wisatawan untuk berkunjung ke Telaga Ngebel (Rusmawati dan Suharti, 2016). Selain mencegah kecelakaan, tradisi upacara ini dimaksudkan untuk menjaga kelestarian budaya Jawa khususnya sebagai kekhasan
Kota Ponorogo. Tujuan lainnya adalah untuk menciptakan kehidupan yang harmonis antara masyarakat lokal dan wisatawan. Namun demikian, hal tersebut akan tercipta jika saling merhargai, menghormati antar sesama, dan menjalankan tradisi sesuai aturan yang berlaku.

Supaya tradisi upacara larung saji tidak hilang nilai sakralnya, maka tradisi ini dilakukan dengan 2 prosesi, yaitu pada malam hari dengan larung buceng beras merah dan pada pagi hari dengan larung buceng agung yang dilakukan oleh pejabat wilayah Kecamatan Ngebel, yang sekaligus sebagai objek pariwisata budaya. Larung yang diadakan pada malam hari merupakan acara inti dan sakral, sedangkan larung yang dilakukan pada pagi hari merupakan perayaan Tahun Baru Hijriyah (Rusmawati dan Suharti, 2016).

\section{Prosesi Tradisi Upacara Larung Saji}

Proses tradisi upacara larung saji dibagi menjadi dua, yaitu proses persiapan dan proses pelaksanaan upacara. Pada proses persiapan dibagi menjadi dua, yaitu persiapan tempat dan persiapan saji. Persiapan tempat dilakukan dengan menghiasi dermaga telaga menggunakan berbagai hiasan dari janur. Hiasan-hiasan tersebut sama halnya pada hiasan upacara pernikahan adat Jawa berupa kembar mayang, kuwade, dan lain-lain. Lapangan juga merupakan tempat kedua yang perlu disiapkan untuk acara upacara. Persiapan 
yang dilakukan adalah dengan membuat panggung, memasang tenda, menata kursi, soundsystem, hingga lampu (Rusmawati dan Suharti, 2016). Saji buceng agung yang digunakan pada upacara dibuat oleh Priyo Handoko yang bertempat tinggal di Dukuh Nglingi Desa Ngebel, dengan tinggi $\pm 1,7$ meter (Rusmawati dan Suharti, 2016).

Nama buceng agung ini karena buceng yang digunakan lebih besar dari buceng beras merah pada upacara malam hari. Karena banyak orang berbondongbondong menyaksikan upacara maka buceng dibuat besar. Hiasan buceng bermacam-macam, mulai dari ingkung (ayam utuh yang dimasak), sayuran, buahbuahan, dan hiasan dari berbagai aneka tanaman. Sayuran yang digunakan untuk menghias buceng antara lain wortel, kacang panjang, sawi, cabe merah, dan sayuran hasil kebun masyarakat sekitar telaga.

Buah-buahan yang digunakan seperti nanas, tomat, jeruk, jambu air, dan buah-buahan hasil kebun lainnya. Hiasan buceng yang berasal dari tanaman seperti daun andong dan daun cemara. Buceng agung dibentuk menjadi beberapa tingkatan, yaitu bagian dasar buceng yang dipasang nampan besar dengan hiasan sayuran dan buah-buahan, bagian bawah buceng terdiri dari beras merah dan dipasang ingkung, sayuran, buah-buahan dan aneka tanaman, dan bagian atas buceng terdiri dari sayuran dan aneka tanaman, pada puncak buceng terdapat tempat khusus untuk tempat cabe merah dan hiasan bunga dari plastik. Di bagian sudut dipasang janur dengan tambahan buahbuahan dan hiasan aneka tanaman. Kebudayaan manusia yang berupa simbol sehingga diwarnai dengan simbolisme, yaitu pola pikir atau kepahaman yang menjadi dasar diri terhadap lambang atau simbol (Endraswara, 2006: 172).

Buceng agung yang akan digunakan untuk larung saji mempunyai arti filosofi atau simbol yang sangat berarti. Buceng agung menggunakan beras merah karena warna merah melambangkan keberanian, menghadapi berbagai cobaan, seperti ditunjukkan pada gambar 2 .

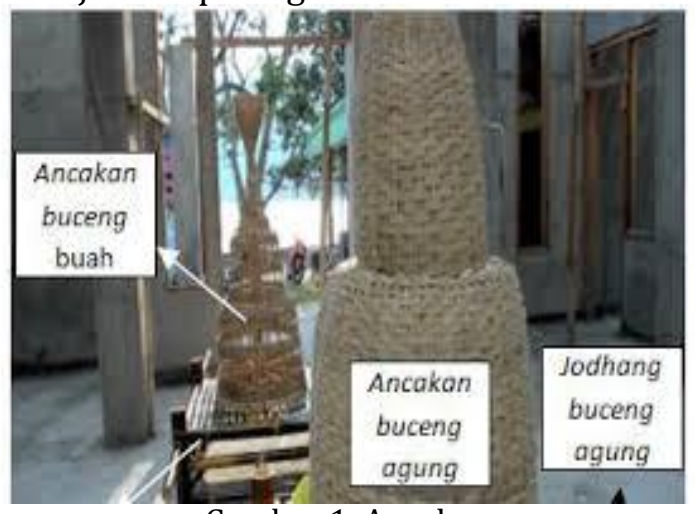

Gambar 1. Ancakan

https://media.neliti.com/media/publications/1 23241-ID-none.pdf

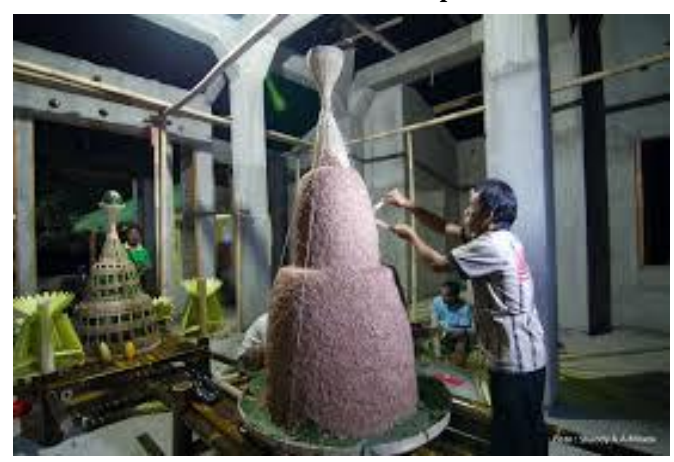

Gambar 2. Membuat Buceng Agung http://wisatajalanceria.blogspot.com/2015/10 /larung-sesaji-di-telaga-ngebel-ponorogo.html 


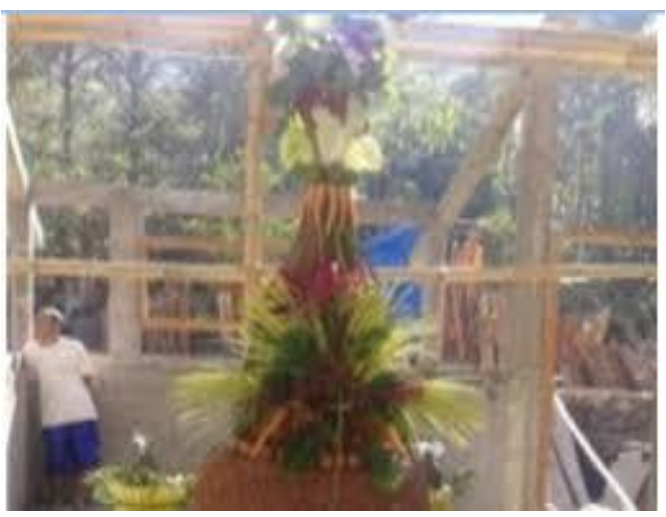

Gambar 3. Buceng Agung

https://media.neliti.com/media/publications/1 23241-ID-none.pdf

Buah-buahan yang digunakan sebagai buceng buah antara lain nanas, semangka, kakao, pisang, tomat, dan lainlain seperti ditunjukkan gambar 4.

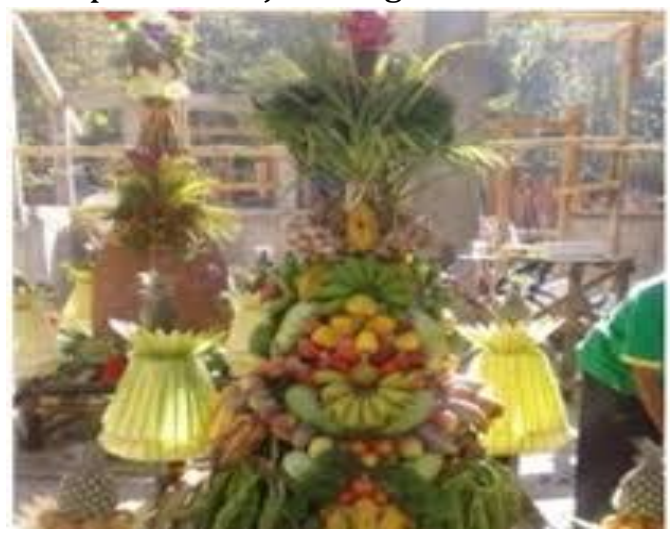

Gambar 4. Buceng Buah

https://media.neliti.com/media/publications/1 23241-ID-none.pdf

Sayuran yang digunakan antara lain petai, terong, dan hasil sayur lainnya. Selain kedua bahan tersebut, bahan untuk hiasan buceng buah lainnya adalah aneka tanaman. Sebenarnya buah-buahan dan sayuran digunakan untuk buceng buah karena wilayah ini mempunyai tata letak di dataran tinggi yang berpotensi menghasilkan hasil bumi berupa tanaman pangan diantaranya buah-buahan dan sayuran.
Buceng buah ini tidak di larung seperti buceng agung, tetapi buceng ini akan diperebutkan oleh masyarakat dan wisatawan yang berada di Telaga Ngebel saat upacara berlangsung. Buceng buah memiliki simbol kemakmuran dari hasil pertanian masyarakat Kecamatan Ngebel. Selain itu juga, untuk menunjukkan rasa syukur kepada Tuhan Yang Maha Esa atas kelimpahan hasil panen.

Puncak kegiatan larung yang diadakan pada pagi hari adalah melarung buceng agung yang telah dibuat ke tengah Telaga. Sebelum acara larung menuju ke tengah Telaga, mereka melakukan upacara terlebih dahulu dengan formasi yang telah ditentukan sejak nenek moyang seperti ditunjukkan pada gambar 6. Salah satu rangkaian acara pada upacara adalah serah terima sesaji dari subamanggala (pemimpin rombongan) kepada Bupati yang selanjutnya akan dilakukan doa bersama seperti ditunjukkan pada gambar 7 .

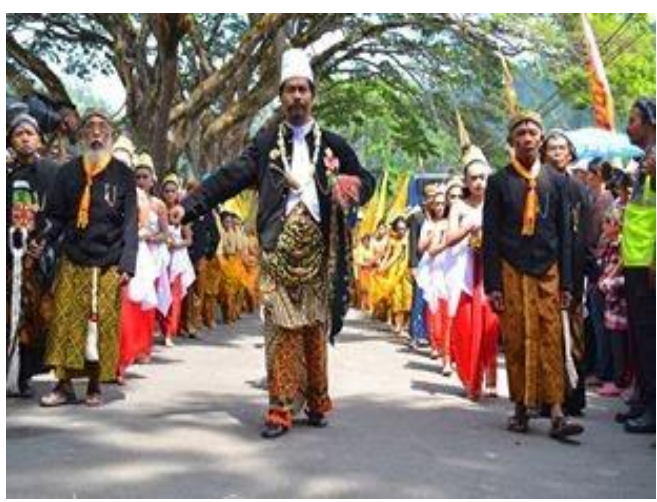

Gambar 5. Rombongan Pembawa Sesaji Memasuki Tempat Upacara

http://wisatajalanceria.blogspot.com/2015/10 /larung-sesaji-di-telaga-ngebel-ponorogo.html 


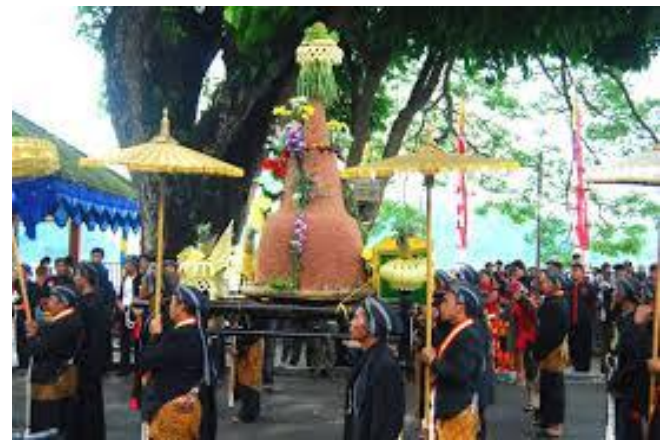

Gambar 6. Prosesi Upacara

http://wisatajalanceria.blogspot.com/2015/10 /larung-sesaji-di-telaga-ngebel-ponorogo.html

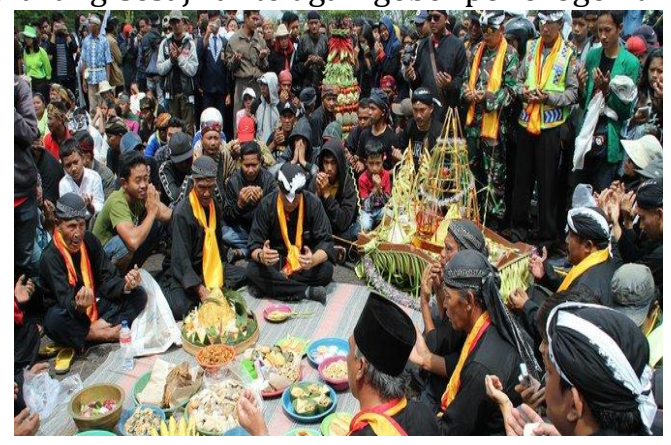

Gambar 7. Doa Bersama

http://wisatajalanceria.blogspot.com/2015/10 /larung-sesaji-di-telaga-ngebel-ponorogo.html

Acara selanjutnya adalah kirab keliling telaga. Tujuannya adalah untuk peringatan Tahun Baru Hijriyah, juga supaya masyarakat dapat melihat buceng yang sudah dibuat dan siap di larung. Setelah kirab selesai, buceng buah menjadi rebutan masyarakat dan wisatawan yang menyaksikan prosesi upacara hingga selesai seperti ditunjukkan pada gambar 8 .

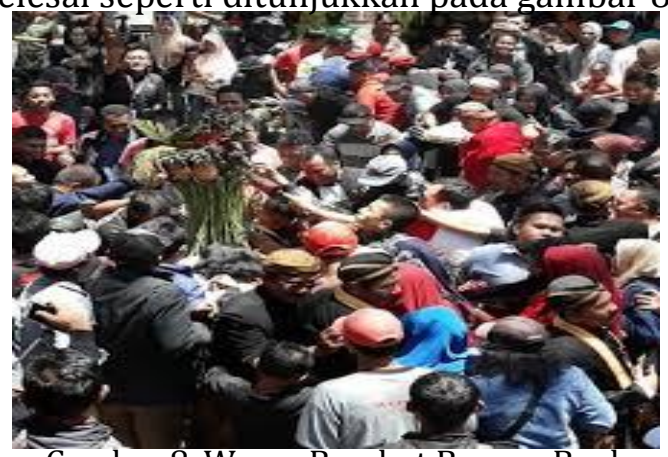

Gambar 8. Warga Berebut Buceng Buah http://wisatajalanceria.blogspot.com/2015/10 /larung-sesaji-di-telaga-ngebel-ponorogo.html
Buceng agung ditata di atas rakit yang terbuat dari bambu wulung sebelum dilarung seperti ditunjukkan gambar 9 .

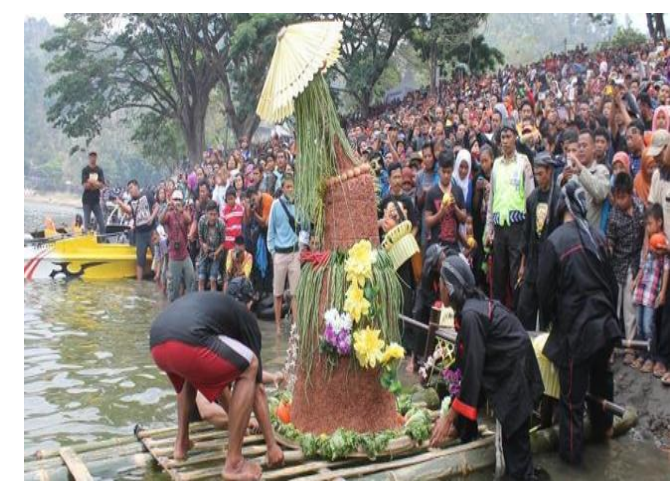

Gambar 9. Buceng agung Ditata Diatas Rakit http://wisatajalanceria.blogspot.com/2015/10 /larung-sesaji-di-telaga-ngebel-ponorogo.html

Masyarakat dan wisatawan sangat antusias dengan adanya prosesi larung saji. Setelah segala persiapan selesai rakit dibawa ke tengah Telaga dengan cara di dorong. Puncak acara adalah pada larungan buceng agung ini, dengan buceng berada di tengah Telaga dan ditenggelamkan, maka berakhirlah acara larungan.

\section{Larung Saji Sebagai Upaya Kelestarian Ekosistem}

Pada prinsipnya manfaat utama upacara larung saji ini adalah untuk memohon keselamatan dengan cara berdoa bersama-sama. Adanya upacara larung saji yang diyakini oleh masyarakat Telaga Ngebel supaya penunggu telaga tidak meminta korban dan pencegahan kecelakaan. Tradisi upacara ini membuktikan bahwa kegiatan sosial semua warga dalam mendapatkan keselamatan. Meramaikan pariwisata dengan lokasi berada di ketinggian \pm 734 mdpl dengan suhu sejuk khas dataran tinggi menjadikan 
tempat ini salah satu wisata alam yang ditonjolkan oleh Kabupaten Ponorogo (Joko, 2009). Wisata Telaga Ngebel biasanya ramai dikunjungi saat hari libur maupun akhir pekan. Banyak kegiatan yang dilakukan wisatawan untuk menikmati keindahan alamnya, salah satu kegiatannya adalah memancing di pinggir Telaga.

Namun, dengan adanya tradisi upacara larung saji ini maka wisatawan yang datang akan semakin banyak, baik dari dalam maupun luar negeri. Selain menikmati pemandangan alam, wisatawan juga dapat menikmati budaya yang sudah melekat dan menjadi agenda tahunan Pemerintah Kabupaten Ponorogo. Persiapan dan pelaksanaan upacara tentu tidak lepas dari gotong royong antar masyarakat. Oleh sebab itu upacara ini dapat meningkatkan hubungan sosial antar masyarakat sekitar Telaga Ngebel maupun wisatawan yang berkunjung.

Selain itu, instansi pemerintah yang terlibat juga saling bertemu dan berinteraksi. Dampak positif yang bisa dirasakan langsung oleh masyarakat sekitar Telaga Ngebel adalah dalam bidang perekonomian. Dengan banyaknya wisatawan maka usaha yang didirikan oleh masyarakat sangat bermacam-macam, seperti berdagang, membuka tempat penginapan, mendirikan warung makan, dan masih banyak lagi cara mereka untuk meraup keuntungan. Selain itu, pengelola sepeda air dan kapal boat juga mendapatkan penghasilan yang meningkat (Joko, 2009). Manfaat adanya tradisi upacara larung saji adalah masyarakat menjadi tahu bahwa pada kenyataannya Kabupaten Ponorogo masih mempunyai wilayah yang sangat alami.

Penulis yang sebelumnya tidak mengetahui bahwa di tempat itu terdapat kawasan hutan lindung dengan beraneka ragam fauna dan flora sekarang menjadi tahu dengan sering datang ke tempat wisata Telaga Ngebel. Ada banyak fauna yang dilindungi terdapat di sekitar Telaga Ngebel. Salah satunya Elang yang banyak dijumpai di Telaga Ngebel (Dian, 2014). Manfaat lain terhadap lingkungan adalah masyarakat maupun wisatawan mampu menjaga dengan baik keindahan alam yang telah diciptakan Tuhan untuk kita. Masyarakat sekitar Telaga juga tidak ada yang berani mengambil hasil alam karena dipercaya masih ada roh-roh yang menunggu di sekitar lokasi. Jadi secara tidak langsung, dengan adanya tradisi larung saji ini sangat bermanfaat bagi masyarakat, wisatawan, dan tentu lingkungan alam yang ada di sekitar Telaga Ngebel (Dian, 2014).

\section{Penutup}

\section{Kesimpulan}

Berdasarkan Tradisi upacara larung saji mempunyai tujuan sebagai tradisi dan pariwisata. Dengan adanya tradisi upacara larung saji diharapkan dapat menarik 
wisatawan untuk berkunjung ke Telaga Ngebel. Dengan banyaknya wisatawan yang berkunjung maka akan sangat memberikan dampak positif bagi perekonomian dan kepariwisataan. Proses tradisi upacara larung saji dibagi menjadi dua, yaitu proses persiapan dan proses pelaksanaan upacara. Tradisi tersebut mempunyai manfaat yakni untuk memohon keselamatan dengan cara berdoa bersamasama, meramaikan pariwisata, serta meningkatkan hubungan sosial ekonomi masyarakat sekitar Telaga Ngebel, serta keterjagaan kelestarian alam.

\section{Daftar Pustaka}

Ali, Lukman, dkk. (1991). Tata Bahasa Baku Bahasa Indonesia (Edisi Kedua). Jakarta: Balai Pustaka.

Badan Pengembangan dan Pengembangan Daerah Kabupaten Ponorogo (BAPPEDA). (2008). Penyusunan Feasibility Study Pengembangan Wisata Ngebel. Ponorogo: Badan Pengembangan dan Pengembangan Daerah Kabupaten Ponorogo (BAPPEDA).

Darmadi, Hamid. (2011). Metode Penelitian Pendidikan. Bandung: Alfabeta.

Data Kependudukan Kabupaten Ponorogo. (2015). Dinas Kependudukan dan Pencatatan Sipil Pemerintah Kabupaten Ponorogo.

Dinas Pekerjaan Umum Bidang Pengairan Kabupaten Ponorogo. (2001-2010). Data Stasiun Hujan. Ponorogo: Dinas Pekerjaan Umum.

Endraswara, S. (2006). Metodologi Penelitian Kebudayaan. Yogyakarta: Gadjah Mada University Press.

Fauza, Nanda. (2010). Istilah-Istilah Sesaji Upacara Tradisional Jamasan Pusaka di Waduk Gajah Mungkur Wonogiri

(Suatu Kajian Etnolinguistik).

Fakultas Sastra dan Seni Rupa Universitas Sebelas Maret Surakarta.

Http://wisatajalanceria.blogspot.com/201 5/10/larung-sesaji-di-telaga-ngebelponorogo.html.

Https://media.neliti.com/media/publicatio ns/123241-ID-none.pdf

Https://www.netizenpintar.com/2018/04 /jalan-menuju-telaga-ngebelponorogo.html

Indrahti, Sri, Siti Maziyah dan Alamsyah. (2017). Ragam Kuliner Sesaji Dalam Upacara Tradisi di Kabupaten Jepara. Semarang: Departemen Sejarah Fakultas Ilmu Budaya Universitas Diponegoro.

Koderi, M. (1991). Banyumas: Wisata dan Budaya. Purwokerto: Metro Jaya.

Koentjaraningrat. (1980). Sejarah Teori Antropologi. Jakarta: Universitas Indonesia.

Koentjaraningrat. (2002). Pengantar Ilmu Antropologi. Jakarta: PT. Rineka Cipta halaman 204.

Maulana Mitanto dan Abraham Nurcahyo. (2012). Ritual Larung Sesaji Telaga Ngebel Ponorogo (Studi Historis dan Budaya). Agastya: Jurnal Sejarah dan Pembelajarannya, 2, 36-53.

Novitasari, Dian. (2014). Analisis Kebijakan Terhadap Pengembangan Pariwisata di Kecamatan Wonosalam Kabupaten Jombang. Surabaya: Program Studi Administrasi Negara Universitas Airlangga.

Nining Nurai'ni, Wakidi, dan Muhammad Basri. (2014). Tradisi Upacara Nadran pada Masyarakat Nelayan Cirebon di Kelurahan Kangkung Bandar Lampung. Pesagi: Jurnal Pendidikan Dan Penelitian Sejarah, 2, 1-14.

Romadhon, Dicky Reza. (2013). Menelisik Nilai-Nilai Kearifan Lokal Dalam 


$\begin{array}{llr}\text { Upacara Tradisi Larung di Sesaji } \\ \text { Telaga Sarangan Desa Sarangan } \\ \text { Kecamatan Plaosan Kabupaten } \\ \text { Magetan. Skripsi. Malang: } & \text { Prodi } \\ \text { Pendidikan Pancasila ran dan } \\ \text { Kewarganegaraan Fakultas Ilmu } \\ \text { Sosial UM Malang. }\end{array}$

Rostiyati, ANI. (1994). Fungsi Upacara Tradisional Bagi Masyarakat Pendukungnya Masa Kini. Yogyakarta: Depdikbud.

Rusmawati dan Suharti. (2016). Tradisi Larungan Buceng Agung di Telaga Ngebel Sebagai Sarana Penarik Wisatawan. Yogyakarta: Fakultas Bahasa dan Seni Universitas Negeri Yogyakarta.

Soemarwoto, Otto. (1983). Ekologi Lingkungan Hidup dan Pembangunan. Jakarta: Djembatan.

Sutarso, Joko. (2009). Menggagas Pariwisata Berbasis Budaya dan Kearifan Lokal. Surakarta: Program Studi Ilmu Komunikasi FKI UMS.

Undang-undang Republik Indonesia Nomor 32 Tahun 2009 tentang Perlindungan dan Pengelolaan Lingkungan Hidup.

Zed, Mestika. (2008). Metode Penelitian Kepustakaan. Jakarta: Yayasan Obor Indonesia. 